\title{
Pasient, klient, bruker eller kunde?
}

Hva er egentlig en pasient? I loven er det definert som «en person som henvender seg til helse- og omsorgstjenesten med anmodning om helsehjelp, eller som helse- og omsorgstjenesten gir eller tilbyr helsehjelp i det enkelte tilfelle» (1). Man trenger altså ikke å være syk, og det er heller ikke nok bare å være syk - man må være i kontakt med profesjonelle hjelpere for å være pasient $\mathrm{i}$ lovens forstand. Men hvor går grensen for pasientbegrepet? For eksempel vil ikke kvinner som ber om p-piller eller abort eller som skal føde, være pasienter i vanlig medisinsk forstand (2). De er ikke syke eller skadet. Likevel faller de inn under lovens pasientbegrep, ettersom de trenger helsevesenets hjelp. Det samme gjelder ellers friske mennesker med forhøyet blodtrykk, forhøyet kolesterolnivå eller andre forhold som gir økt risiko for sykdom. Skal disse også kalles pasienter?

Mange har kritisert pasientbegrepet. Ordet pasient går tilbake til et latinsk ord, patiens, som bl.a. hadde betydningen «som lider» eller «lidende». Det er ikke dekkende for mange av dem som oppsøker dagens helsevesen. Noen foretrekker derfor heller begrepet «klient» (3). Men etymologien - læren om ords opphav - hjelper heller ikke her. Cliens på latin er betegnelsen på en person som stiller seg under en mektig manns beskyttelse, altså ikke særlig mer moderne eller nøytralt enn pasient.

Andre har påpekt at pasientbegrepet er historisk ladet. Tidligere var pasientbehandlingen preget av paternalisme - en allvitende, dominerende lege og en passiv, adlydende pasient, arketypen på et ulikeverdig maktforhold. Nå er idealet den kunnskapsrike og aktive ekspertpasienten som stiller krav til legen (4). Det kan hevdes at den nye pasientrollen er så annerledes enn den gamle at pasientbegrepet bør avvikles $(5,6)$. Mange med kronisk sykdom ønsker dessuten ikke å se på seg selv som pasient til daglig. De vil heller legge vekt på andre og viktigere forhold ved seg selv - en person med astma vil heller oppfattes som familiefar og arbeidstaker enn som astmapasient (4). En slik synsvinkel kan bidra til å dyrke de friske sidene ved et menneske, slik at man frigjør seg fra en passiv pasientrolle som kan fremme sykelighet og hindre tilfriskning. Mange som søker eller får psykiatrisk hjelp, vil ikke se på seg selv som pasient. Enkelte har argumentert for at «overlever» (survivor) kan være et passende alternativ til begrepet pasient. Personer på sykehjem omtales ofte som «beboere». Det kan virke søkt hvis de er svært syke.

Hva mener så «pasientene» selv? Det finnes mengder av kommentarer og meningsytringer, men få har tatt seg bryet med å spørre dem det gjelder (7). Ifølge en fersk oversiktsartikkel viser forsk- ningslitteraturen innen psykiatrien at det som finnes av empiriske undersøkelser, ikke gir sikker kunnskap om hvilken betegnelse pasientene selv foretrekker (8).

Det har altså vist seg vanskelig å finne gode alternativer for ordet pasient. «Bruker», «forbruker» og «kunde» er foreslått. Betegnelsen «bruker» er etter loven noe annet enn pasient. En bruker er «en person som anmoder om eller mottar tjenester omfattet av helse- og omsorgstjenesteloven som ikke er helsehjelp» (1). Når det gjelder betegnelsen «kunde», vil mange finne det uheldig å bruke handelstermer for å beskrive forholdet mellom legen og den som søker legens hjelp. Slik ordbruk innebærer at legen er tilbyder og at pasienten bestiller tjenester. Dette kan være problematisk, for eksempel når folk søker lege fordi de vil ha antibiotika, vanedannende legemidler, sykmelding eller selvbestemt keisersnitt. Kundemetaforen er uheldig fordi det trekker medisinen i retning av rendyrket økonomi og er en trivialisering av lege-pasient-forholdet $(9,10)$. Et kundeforhold er ikke forenlig med legers tradisjonelle verdigrunnlag, som er omsorg for enkeltmennesket.

Det høres så fint å være kunde - man har jo alltid rett - men underteksten er truende. Ansvaret flyttes på subtilt vis over på den hjelptrengende. Det er alltid de mest ressurssterke og kompetente kundene som får den beste varen til lavest pris. Vi andre må som regel stille oss lenger bak i køen og får dårligere service og varer. Ordet «kunde» fjerner noe av det mest sentrale aspektet ved vårt helsevesen - nemlig at fellesskapet tar ansvar for oss og hjelper oss når vi er syke og sårbare.

\footnotetext{
Litteratur

1. LOV 1999-07-02 nr. 63: Lov om pasient- og brukerrettigheter (pasient- og brukerrettighetsloven). www. lovdata.no/all/hl-19990702-063.html (16.4.2013). 2. Warberg LA. Norsk helserett. 2. utg. Oslo: Universitetsforlaget, 2011: 71, 312.

3. Pasient (Store medisinske leksikon). I: Store norske leksikon. http://snl.no/.sml artikkel/pasient (16.4.2013).

4. Smith R. The discomfort of patient power. BMJ 2002; 324: 497-8.

5. Reeder LG. The patient-client as a consumer: some observations on the changing professional-client relationship. J Health Soc Behav 1972; 13: 406-12.

6. Rada RT. The health care revolution: from patient to client to customer. Psychosomatics 1986; $27: 276-9,283-4$

7. Neuberger J. Do we need a new word for patients? Lets do away with «patients». BMJ 1999; 318: $1756-7$.

8. Dickens G. Picchioni M. A systematic review of the terms used to refer to people who use mental health services: user perspectives. Int J Soc Psychiatry 2012; 58: $115-22$.

9. Andreasen NC. Clients, consumers, providers, and products: where will it all end? Am J Psychiatry 1995; 152: 1107-9.

10. Krugman P. Patients are not consumers. New York Times 21.4.2011. www.nytimes.com/2011/04/22/opinion/22krugman.html? r=1 (16.4.2013).
} 